\title{
Phyto-Chemical Studies of Methanol Extract of Tinospora cordifolia Leaf by GC-MS
}

\author{
S. Jebaseelan ${ }^{1 *}$, B. Edwin Jose ${ }^{2}$, Dr.R.Meera ${ }^{3}$ \\ 1,3 Department of Pharmaceutical Chemistry, Ultra College of Pharmacy, Madurai, India. \\ ${ }^{2}$ Department of Pharmaceutical Chemistry, Sankaralingam Bhuvaneswari College of Pharmacy, Sivakasi, India \\ *Corresponding author's E-mail: jebaseelanmpharm2000@rediffmail.com
}

Received: 24-02-2021; Revised: 15-04-2021; Accepted: 23-04-2021; Published on: 15-05-2021.

\section{ABSTRACT}

Plants are the almost exclusive source of drugs for the majority of the world population. The present study was carried out to investigate the phytoconstiuent of the Tinospora cordifolia leaf which contain alkaloids, flavanoids, steroidal glycoside, terpenoids and sterol are confirmed by preliminary phyochemical studies. GC-MS analysis of methanol extract of the plant Tinospora cordifolia leaf showed the presence of 15 bio active compounds. They are 4H-Pyran-4-one, 2,3-dihydro-3,5- dihydroxy-6-methyl,1,2,3propanetriol,2-methoxy-4-vinylphenol, Benzene, 1-(2-chloroethyl)-2-(trifluoromethyl),3-Hydroxy-4-methoxybenzoic acid, nHexadecanoic acid, Hexadecanoic acid, ethyl ester,9,12-Octadecadienoic acid (Z,Z)-,methyl ester, Oleic Acid, Linoleic acid ethyl ester,9-octadecenoic acid (z)-, ethyl ester, octadecanoic acid, ethyl ester,2,4-imidazolidinedione, 5,5- diphenyl-, hexadecanoic acid, 2-hydroxy-1-(hydroxymethyl)ethyl ester.

Keywords: Tinospora cordifolia, phyto-constituent, GC-MS analysis, bioactive compound.

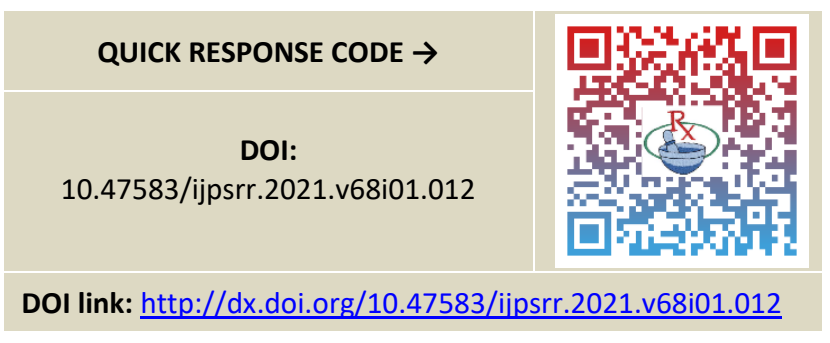

\section{INTRODUCTION}

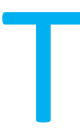

he Tinospora cordifolia has been subjected to chemical investigation extensively and number of chemical constituents belonging to the different groups viz terpenoid, alkaloids, lignans, steroids have been analysed.

Herbal plants produce and contain a variety of chemical substances with varied physiological effects. They are huge reservoir of various chemical substances with potential therapeutic properties ${ }^{1}$. Herbal plants are being increasingly utilized to treat a wide variety of clinical diseases 2. Herbs have been used by all cultures throughout history and thus, herbal medicine is the oldest form of health care known to mankind. It was an integral part of the development of modern civilization. Many drugs commonly used today are of herbal origin. Higher plants as source of medicinal compound continue to play a dominant role in maintenance of human health since antiquities ${ }^{3}$.

\section{MATERIALS AND METHODS}

\section{Collection of samples}

The leaf Tinospora cardifolia was collected in Dindigul district of Tamilnadu during the first week end of
December. This plant was authenticated by the Department of the Botany, American College, Madurai.

Extracted plant material powder by maceration method.

The shade dried material (250gms) was extracted with petroleum ether $\left(60^{\circ} \mathrm{C}-80^{\circ} \mathrm{C}\right)$ in soxhlet apparatus. After the completion of the extraction, the solvent was removed. The marc left petroleum ether extraction was dried and extracted with chloroform in soxhlet apparatus. The solvent was removed after the completion of extraction. The marc left after the chloroform extraction was dried and then extracted with ethanol in soxhlet apparatus. The solvent was removed after the extraction was completed, the solvent was taken out and concentrated.

\section{Preparation of sample for phytochemical screening}

The plant parts (leaf) were cleaned, dried and powdered with the help of mixer grinder separately. Methanol extracts were prepared and concentrated using rotary evaporator and stored at $4{ }^{\circ} \mathrm{C}$ in air tight containers.

\section{Preparation of extract for Gas Chromatography Mass Spectroscopy (GC-MS) Analysis}

15 grams of dried leaf powder of Tinospora cordifolia was taken and soaked in $\mathbf{1 5 0}$ methanol and it was kept in room temperature for 72 hours with constant shaking. After incubation, solutions were filtered with whattman filter paper no. 1 and filtrate were kept at room temperature for drying. After drying, the weight of extract was measured and according to weight solvent was added and maintained the concentration of extract as $25 \mathrm{mg} / \mathrm{ml}$. 


\section{Methodology for phytochemical screening ${ }^{4-7}$}

Chemical tests were carried out on the extract and on the powdered specimens using standard procedures based on the protocols of Edeoga et al,2005; Harborne,1973and Sofowara,1993;to identify the various constituents present.

\section{Test for Alkaloids}

Test solution ( $1 \mathrm{ml}$ ) was taken in test tube and few drops of Mayer's reagent (Potassium mercuric iodine solution) were added into it and then cream color precipitate was observed. To a few $\mathrm{ml}$ of filtrate, 1 or $2 \mathrm{ml}$ of Dragendorff's reagent was added by the side of the test tube. A prominent red precipitate indicates test as positive.

\section{Test for Tannins}

To test solution added $10 \mathrm{ml}$ distilled water, then filtered, in the filtrate $2 \mathrm{ml} \mathrm{FeCl} 3$ (10\%) was added blue-black or green precipitate formed, indicate the presence of tannins.

\section{Test for Cardiac Glycosides}

$5 \mathrm{ml}$ of each extracts was treated with $2 \mathrm{ml}$ of glacial acetic acid containing onedrop of ferric chloride solution. This was underlayed with $1 \mathrm{ml}$ of concentrated sulphuric acid. A brown ring of the interface indicates a deoxysugar characteristic of cardenolides. A violet ring may appear below the brown ring, while in the acetic acid layer, a greenish ring may form just gradually throughout thin layer.

\section{Test for Flavonoid}

$5 \mathrm{ml}$ of dilute ammonia solution were added to a portion of the aqueous filtrate of each plant extract followed by addition of concentrated $\mathrm{H} 2 \mathrm{SO} 4$. A yellow coloration observed in each extract indicated the presence of flavonoids. The yellow coloration disappeared on standing. Test for Terpenoids to the test solution, added $2 \mathrm{ml}$ of chloroform and $1 \mathrm{ml} \mathrm{H} 2 \mathrm{SO} 4$, reddish brown color at interface, indicate the presence of terpenoids.

\section{Test for Saponins}

$2 \mathrm{gm}$ of the powdered sample was boiled in $20 \mathrm{ml}$ of distilled water in a water bath and filtered. $10 \mathrm{ml}$ of the filtrate was mixed with $5 \mathrm{ml}$ of distilled water and shaken vigorously for a stable persistent froth. The frothing was mixed with 3 drops of olive oil and shaken thoroughly, then observed for the formation of emulsion thereafter in plant sample (filterate/powder).

\section{Test for Steroids}

$2 \mathrm{ml}$ of acetic anhydride was added to $0.5 \mathrm{gm}$ ethanolic extract of each sample with $2 \mathrm{ml} \mathrm{H} 2 \mathrm{SO}$. The colour changed from violet to blue or green in some samples indicating the presence of steroids.

\section{RESULT AND DISCUSSION}

\section{Phytochemical Screening}

\section{Qualitative estimation}

In the present study, preliminary phytochemical screening of the extract of leaves of experimental plant T.cordifolia, revealed the presence of various bioactive components such as alkaloids, saponins, tannins, cardiac glycosides, steroids, flavonoids, terpenoids etc were identified.

Table 1: Phytochemical screening of leaf parts of Tinospora cordifolia

\begin{tabular}{|c|c|c|c|c|c|c|c|}
\hline S. No & Tannins & Saponins & Steroids & Terpenoids & Flavonoids & Alkaloids & Cardiac glycosides \\
\hline+ or - & + & + & + & + & + & + & + \\
\hline
\end{tabular}

\section{Gas Chromatography -Mass Spectroscopy (GC-MS) Analysis $^{8}$}

For GC-MS analysis, methanolic extract of the plant sample (leaf) was sent to Bishop heber college, Herbal analytical instrument facility, Trichy. The results of GC-MS analysis of Tinospora cordifolia extracts were very interesting. GC-MS of the T.Cordifolia extract revealed the presence of 15 components having different pharmacological importance.

\section{GC Programme [GCMS-QP2020]}

$\begin{array}{ll}\text { Ion Source Temp. } & : 200.00 \mathrm{C} \\ \text { Interface Temp. } & : 250.00 \mathrm{C} \\ \text { Solvent Cut Time } & : 3.50 \mathrm{~min} \\ \text { Detector GainMode } & : \text { Relative to the Tuning Result } \\ \text { Detector Gain } & :+0.00 \mathrm{kV} \\ \text { Threshold } & : 1000\end{array}$

\begin{tabular}{|c|c|c|c|} 
Oven temperature Programme \\
\hline S.no & Rate & Temperature $\left({ }^{\circ} \mathrm{C}\right)$ & Hold Time (min) \\
\hline 1 & - & 50.0 & 0.00 \\
\hline 2 & 6.00 & 280.0 & 2.00 \\
\hline
\end{tabular}

\section{MS Programme}

$\begin{array}{ll}\text { Start time } & : 4.00 \mathrm{~min} \\ \text { End time } & : 40.33 \mathrm{~min} \\ \text { ACQ mode } & : \text { Scan } \\ \text { Event time } & : 0.3 \mathrm{sec} \\ \text { Scan speed } & : 1666 \\ \text { Start m/z } & : 50.00 \\ \text { End m/z } & : 500.00 \\ \text { Sample inlet unit } & : G C\end{array}$


Table 2: Components identified in Tinospora Cardifolia [GC MS study]

\begin{tabular}{|c|c|c|c|c|c|}
\hline No. & RT & Name of the compound & Molecular Formulae & MW & Peak Area \% \\
\hline 1. & 10.394 & $\begin{array}{l}\text { 4H-Pyran-4-one, 2,3-dihydro-3,5- } \\
\text { dihydroxy-6-methyl- }\end{array}$ & $\mathrm{C} 6 \mathrm{H} 8 \mathrm{O} 4$ & 144 & 0.62 \\
\hline 2. & 11.358 & 1,2,3-propanetriol & $\mathrm{C} 3 \mathrm{H} 8 \mathrm{O} 3$ & 92 & 1.1 \\
\hline 3. & 14.191 & 2-methoxy-4-vinylphenol & $\mathrm{C} 9 \mathrm{H} 10 \mathrm{O} 2$ & 150 & 2.05 \\
\hline 4. & 15.39 & $\begin{array}{l}\text { benzene, 1-(2-chloroethyl)-2- } \\
\text { (trifluoromethyl)- }\end{array}$ & $\mathrm{C} 9 \mathrm{H} 8 \mathrm{C} 1 \mathrm{~F} 3$ & 208 & 0.58 \\
\hline 5. & 19.96 & 3-hydroxy-4-methoxybenzoic acid & $\mathrm{C} 8 \mathrm{H} 8 \mathrm{O} 4$ & 168 & 0.65 \\
\hline 6. & 20.153 & 3-hydroxy-4-methoxybenzoic acid & $\mathrm{C} 8 \mathrm{H} 8 \mathrm{O} 4$ & 168 & 1.56 \\
\hline 7. & 21.178 & benzoic acid, 3,4-dimethoxy- & $\mathrm{C9H} 1004$ & 182 & 0.56 \\
\hline 8. & 26.803 & n-hexadecanoic acid & $\mathrm{C} 16 \mathrm{H} 32 \mathrm{O} 2$ & 256 & 3.97 \\
\hline 9. & 27.175 & hexadecanoic acid, ethyl ester & $\mathrm{C} 18 \mathrm{H} 36 \mathrm{O} 2$ & 284 & 4.7 \\
\hline 10. & 28.73 & 9,12-octadecadienoic acid ( $z, z)$-, methyl ester & $\mathrm{C} 19 \mathrm{H} 34 \mathrm{O} 2$ & 294 & 0.98 \\
\hline 11. & 29.563 & 9,12-octadecadienoic acid $(z, z)$ - & $\mathrm{C} 18 \mathrm{H} 32 \mathrm{O} 2$ & 280 & 6.92 \\
\hline 12. & 29.634 & oleic acid & $\mathrm{C} 18 \mathrm{H} 34 \mathrm{O} 2$ & 282 & 6.05 \\
\hline 13. & 29.797 & linoleic acid ethyl ester & $\mathrm{C} 2 \mathrm{OH} 36 \mathrm{O} 2$ & 308 & 13.06 \\
\hline 14. & 29.887 & 9-octadecenoic acid (z)-, ethyl ester & $\mathrm{C} 2 \mathrm{OH} 38 \mathrm{O} 2$ & 310 & 10.04 \\
\hline 15. & 30.259 & octadecanoic acid, ethyl ester & $\mathrm{C} 2 \mathrm{OHOO} 2$ & 312 & 1.05 \\
\hline 16. & 33.281 & 2,4-imidazolidinedione, 5,5- diphenyl- & $\mathrm{C} 15 \mathrm{H} 12 \mathrm{~N} 2 \mathrm{O} 2$ & 252 & 1.08 \\
\hline 17. & 34.677 & $\begin{array}{l}\text { hexadecanoic acid, 2-hydroxy-1- } \\
\text { (hydroxymethyl)ethyl ester }\end{array}$ & $\mathrm{C} 19 \mathrm{H} 3804$ & 330 & 0.91 \\
\hline 18. & 37.051 & e,z-1,3,12-nonadecatriene & $\mathrm{C} 19 \mathrm{H} 34$ & 262 & 10.8 \\
\hline 19. & 37.587 & -1-benzopyran-2-one, 7-hydroxy-3- (4-methoxyphenyl)- & $\mathrm{C} 16 \mathrm{H} 12 \mathrm{O} 4$ & 268 & 11.49 \\
\hline 20. & 37.805 & $\begin{array}{l}\text { 2-(4-dicyanomethyl-2,3,5,6-tetrafluorophenyl) } \\
\text { malononitrile }\end{array}$ & $\mathrm{C} 12 \mathrm{H} 2 \mathrm{~F} 4 \mathrm{~N} 4$ & 278 & 0.66 \\
\hline 21. & 37.963 & 'h-furo[3,2-g][1]benzopyran-7-one, 2,3,5-trimethyl- & $\mathrm{C} 14 \mathrm{H} 12 \mathrm{O} 3$ & 228 & 2.59 \\
\hline 22. & 38.089 & n,o-dimethylstephine & $\mathrm{C} 2 \mathrm{OH} 25 \mathrm{NO} 6$ & 375 & 2.41 \\
\hline 23. & 38.223 & (+)-isostephodeline & $\mathrm{C} 21 \mathrm{H} 27 \mathrm{NO} 05$ & 373 & 4.6 \\
\hline 24. & 38.387 & $\begin{array}{l}\text { 1,3,8-trimethoxy-6- } \\
\text { methylanthracen-9-ol }\end{array}$ & $\mathrm{C} 18 \mathrm{H} 1804$ & 298 & 0.74 \\
\hline 25. & 38.48 & 2-[(1 hydroxy)hexyl]indol-3-acetic acid & $\mathrm{C} 16 \mathrm{H} 21 \mathrm{NO} 3$ & 275 & 1.62 \\
\hline 26. & 38.61 & $\begin{array}{c}\text { phenol, 3-[2-(dimethylamino)ethyl]-6- methoxy-2- } \\
{[2-(4-\text { methoxyphenyl)ethenyl]-, }} \\
\text { (e)- }\end{array}$ & $\mathrm{C} 2 \mathrm{OH} 25 \mathrm{NO} 3$ & 327 & 0.61 \\
\hline 27. & 38.76 & $\begin{array}{l}\text { 3-hydroxy-4,7,8-trimethoxy- } \\
\text { 17-methyl-7,8- didehydrohasubanan-6-one \# }\end{array}$ & $\mathrm{C} 20 \mathrm{H} 25 \mathrm{NO} 5$ & 359 & 0.72 \\
\hline 28. & 33.876 & $\begin{array}{c}\text { dibenz }[\mathrm{a}, \mathrm{c}] \text { cycloheptan-7-amine, } \\
\text { 1,2,3-trimethoxy- }\end{array}$ & $\mathrm{C} 18 \mathrm{H} 21 \mathrm{NO} 3$ & 299 & 1.22 \\
\hline 29. & 39.101 & $\begin{array}{l}\text { (7as)-11-methoxy-6,7,7a,8- tetrahydro-5h- } \\
\text { 1,3]benzodioxolo[6,5,4- } \\
\text { de]benzo[g]quinolin-12-ol }\end{array}$ & $\mathrm{C} 18 \mathrm{H} 17 \mathrm{NO} 4$ & 311 & 0.53 \\
\hline 30. & 39.766 & benzofuran, 6-methoxy-2-(2,4,6-trimethoxyphenyl)- & $\mathrm{C} 18 \mathrm{H} 1805$ & 314 & 6.1 \\
\hline
\end{tabular}



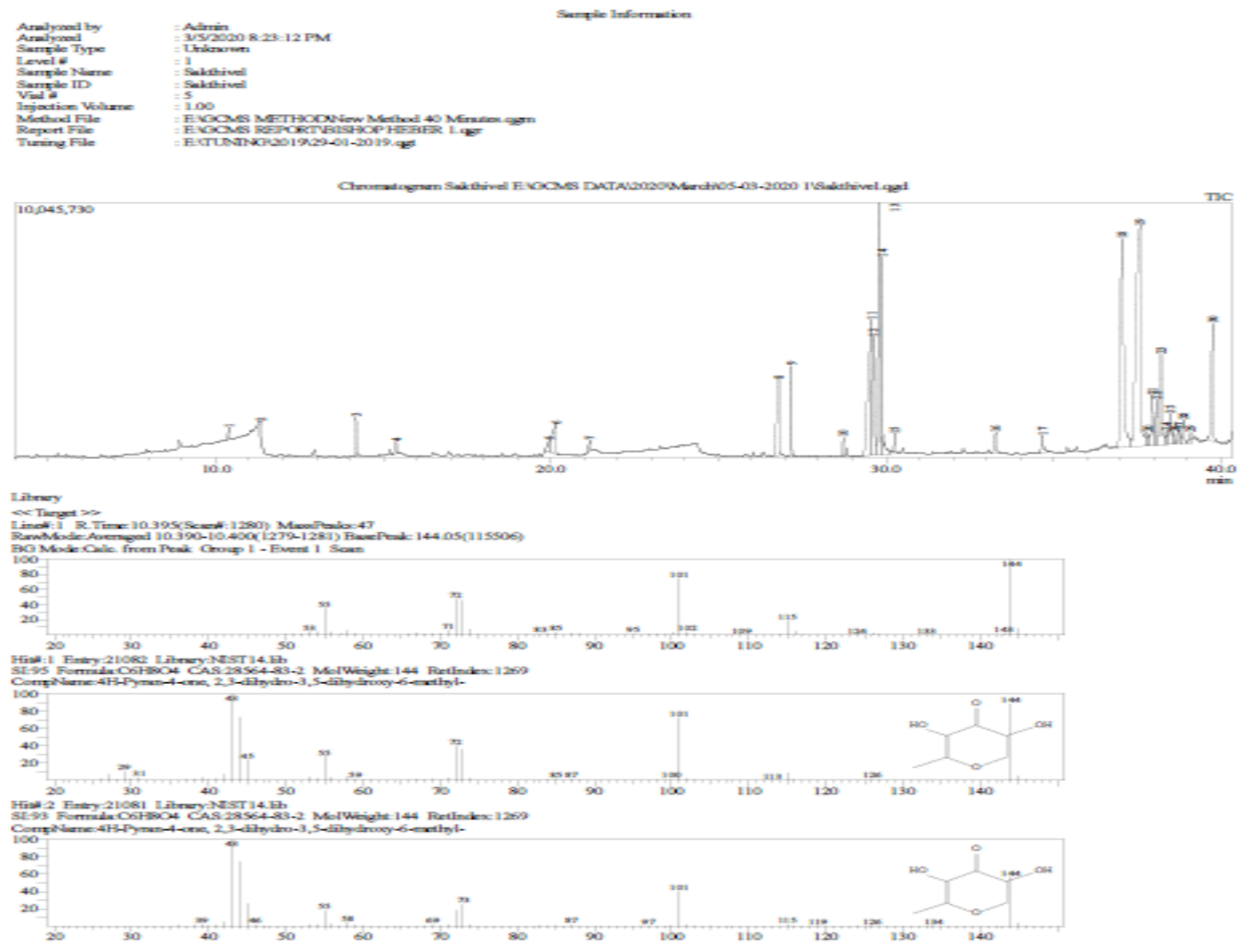

BISHOP HEBER COLLEGE

HEBER ANALYTICAL INSTRUMENTATION FACILITY

$\ll$ Target $\gg$

Line 16 R.Time:33.280(Scant:5857) MassPeaks: 121

RawMode:Averaged 33,275-33.285(5856-5858) BasePeak: 180.05(1235-45)

BG Mode:Cale, from Peak Group I - Event 1 Scar

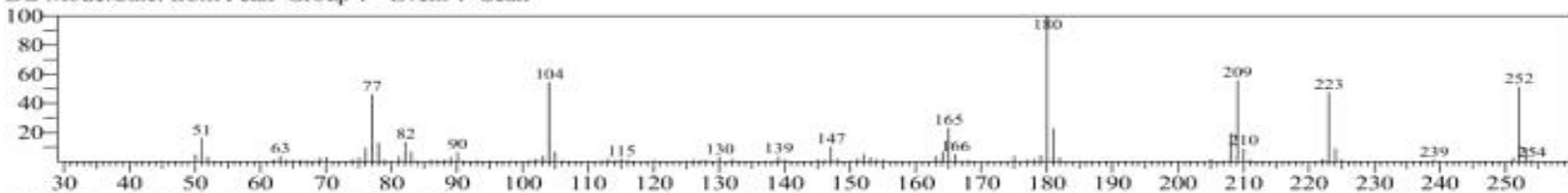

Hiti:1 Entry: 177248 Liborary:WILEY8.LIB

S1:95 Formula: $15 \mathrm{H} 12 \mathrm{~N} 2 \mathrm{O} 2$ CAS:57-41-0 MolWeight:252 Retlndex:0

CompName-2,4-IMIDAZOLIDINEDIONE, 5,5-DIPHENYL- \$S 5,5-DIPHENYUIMIDAZOLIDINE-2,4-DIONE \$S 2,4-IMIDAZOLIDINEDIONE, 1,3-DI

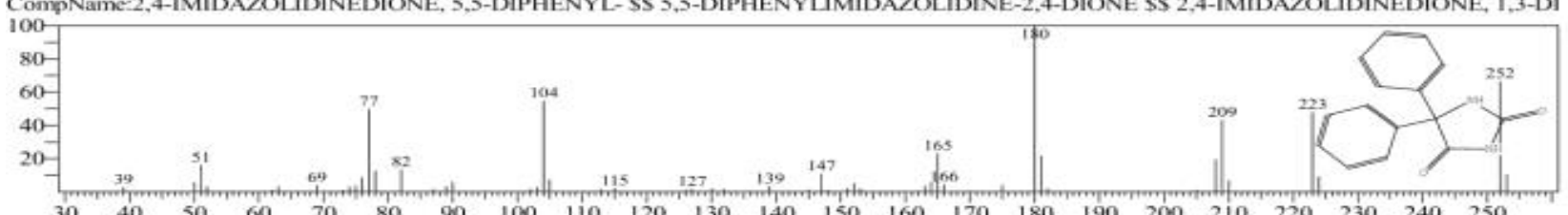

Entry:177181 Library:WILEY8.LIB

Hiti:2 Entry:177181 Library:WILEY8.L1B

CompName:2,4-IMIDAZOLIDINEDIONE, 5,5-DIPHENYL-SS 5,5-DIPHENYUIMIDAZOLIDINE-2,4-DIONE \$S 2,4-IMIDAZOLIDINEDIONE, 1,3-DI

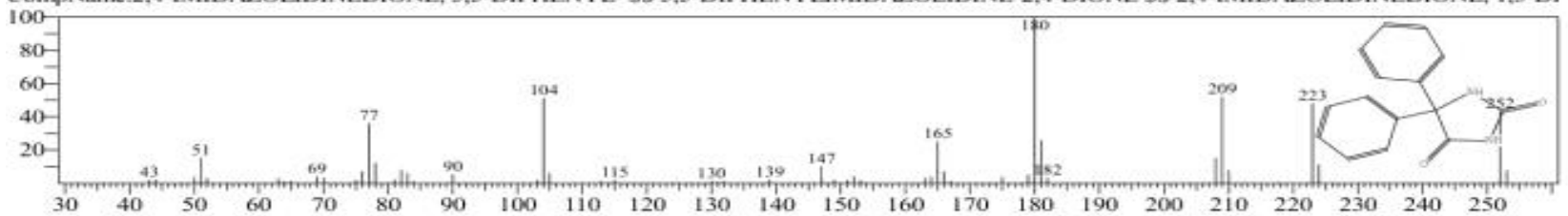




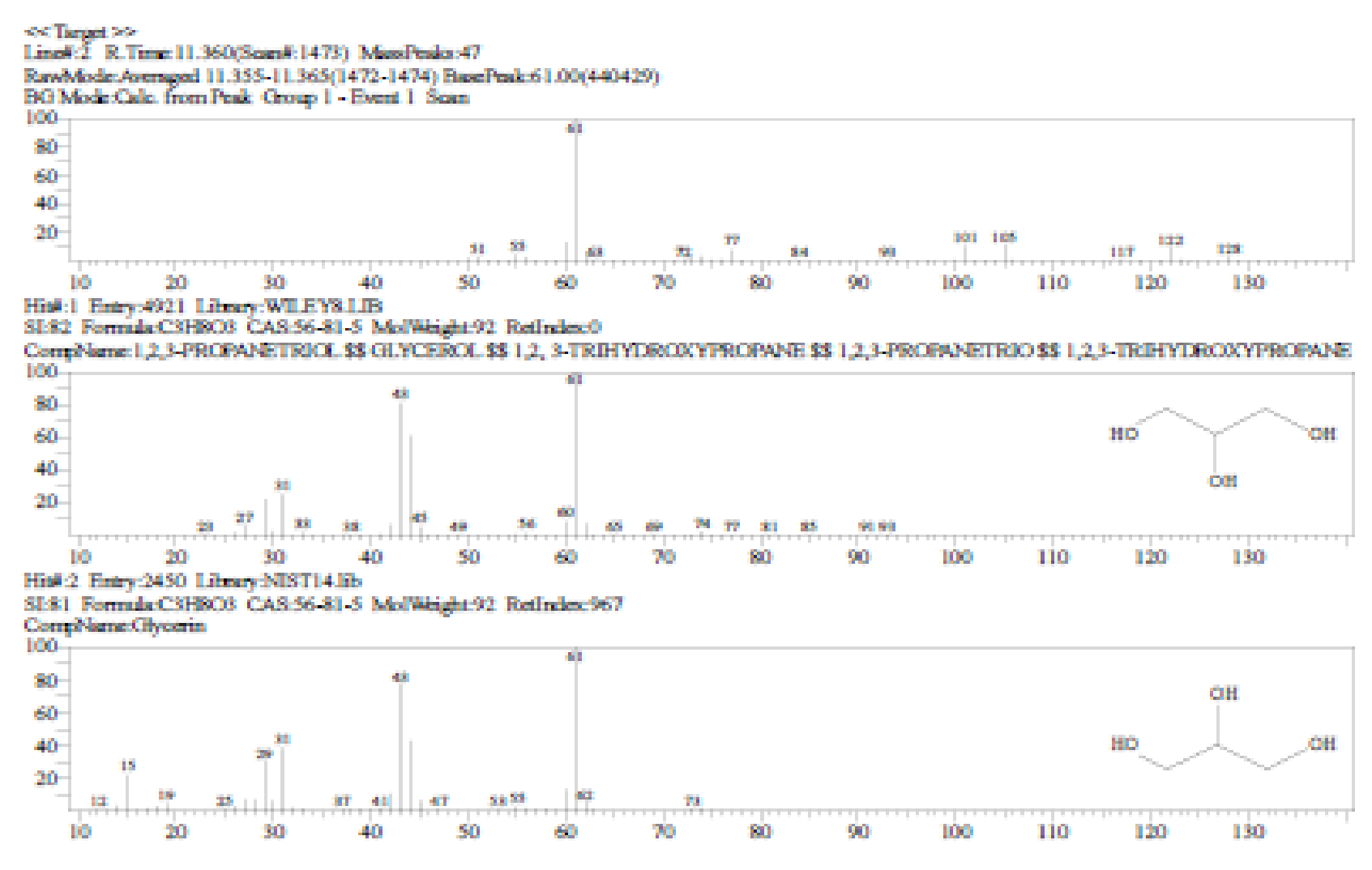

\section{RESULTS AND DISCUSSION}

Fifteen components in leaves were identified in Tinospora cordifolia by Gas Chromatogram-Mass spectrometry (GCMS) analyzed. GC MS Studies of Tinospora cordifolia indicates that the prevailing components were the presence of various bioactive components justifies the use of the whole plant for various ailments by traditional practitioners. The active principles with their retention time (RT), molecular formula, molecular weight (MW) and concentration (\%) are presented. The prevailing components were The GC-MS analysis revealed the presence of various components like 4H-Pyran-4-one, 2,3-dihydro-3,5- dihydroxy-6-methyl,1,2,3propanetriol,2-methoxy-4-vinylphenol,Benzene, 1-(2chloroethyl)-2-(trifluoromethyl),3-Hydroxy-4-

methoxybenzoic acid, n-Hexadecanoic acid, Hexadecanoic acid, ethyl ester,9,12-Octadecadienoic acid (Z,Z)-,methyl ester, Oleic Acid, Linoleic acid ethyl ester,9-octadecenoic acid (z)-, ethyl ester, octadecanoic acid, ethyl ester,2,4-imidazolidinedione,5,5-diphenyl,hexadecanoic acid, 2-hydroxy-1-(hydroxymethyl)ethyl ester.(Table2) This study explores the goodness of the leaf of the plant Tinospora cordifolia which has a commendable sense of purpose and can be advised as a plant of phyto pharmaceutical importance. GC-MS figure for $4 \mathrm{H}-\mathrm{Pyran}-4-$ one, 2,3-dihydro-3,5- dihydroxy-6-methyl,2,4imidazolidinedione, 5,5- diphenyl-, hexadecanoic acid, 1,2,3-propanetriol,2-methoxy-4-vinylphenol ,(Figure 1-3). This study explores the goodness of the leaf of the plant Tinospora cordifolia which has a commendable sense of purpose and can be advised as a plant of phyto pharmaceutical importance.

\section{CONCLUSION}

Knowledge of chemical constituents of plants is important and desirable because such information will be important for synthesis of chemical substances. It could be well qualified for application in pharmaceutical industry. The GC-MS analysis of methanolic extract of experimental plant showed the presence of pharmacologically active compounds such as antioxidant and antihyperlipidemic. This plant can be saved through biotechnological approaches and its quality can be improved through secondary metabolites production and thus it can be used as a source for developing new drugs and commercialization.

\section{REFERENCES}

1. Ashis G. Herbal folk remedies of Bankura and Medinipur districts, West Bengal. Indian Journal of Traditional Knowledge 2003; 2: 393-396.

2. RajparaN, Patel A, Tiwari N, Bahuguna J, Antony A, Choudhury I, Ghosh A, Jain R, Bhardwaj AK. Mechanism of drug resistance in a clinical isolate of Vibrio fluvialis: involvement of multiple plasmids and integrons. Int J Antimicrob Agents.2009; 34: 220-225

3. Roberts MC.Tetracycline resistance determinants: mechanisms of action, regulation of expression, genetic mobility, and distribution. FEMS Microbiol Rev.1996; 19: 1-24.

4. Edeoga H.O, Okwu D.E. Mbaebie BO. Phytochemical constituents of some Nigerian medicinal Plants. AfricanJournal of Biotechnology, 2005; 4(7): 685-688. 
5. Harada H, Yamashita U, Kurihara H, Fukushi E, Kawabata J. Kamei Y. Anti tumoractivity of palmitic acid found as a selective cytotoxic substance in a marine red alga. Anti cancerRes, 2002; 22(5): 25872590.

6. Sofowara, A. Medicinal plants and traditional medicine in Africa. Spectrum Books Ltd., Ibadan, Nigeria, 1993; 289.
7. Harborne J.B. Phytochemical methods, London. Chapman and Hall Ltd. 1973; 49: 188.

8. Preeti. Tinospora cordifolia-A miracle herb and lifeline tomany disease. Int. J.Med. Arom.Plant,2011; 1(2): 57-61.

\section{Source of Support: None declared.}

Conflict of Interest: None declared.

For any question relates to this article, please reach us at: editor@globalresearchonline.net New manuscripts for publication can be submitted at: submit@globalresearchonline.net and submit_ijpsrr@rediffmail.com 